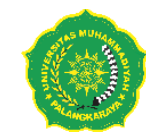

UMP

SULUH

JURNAL BIMBINGAN DAN KONSELING

http: //journal. umpalangkaraya. ac. id/index. php/suluh Volume 4 Nomor 2, Februari 2019 (14-20)

\title{
PERAN KONSELOR DALAM PENANGGULANGAN PERGAULAN BEBAS DI KALANGAN REMAJA (Studi Kasus di SIMA Muhammadiyah 2 Palangkaraya)
}

\section{ROLE OF COUNSELORS IN MITIGATION PROMISCUITY AMONG TEENS(Case Study at Muhammadiyah 2 High School in Palangkaraya)}

\author{
'M. Andi Setiawan, ${ }^{2}$ Heru Nurochman
}

'Universitas Muhammadiyah palangkaraya, Palangka Raya, Kalimantan Tengah, Indonesia

${ }^{2}$ Universitas Muhammadiyah palangkaraya, Palangka Raya, Kalimantan Tengah, Indonesia

\begin{abstract}
ARTIKEL INFO
ABSTRAK

Diterima

Januari 2019

Dipublikasi

Februari 2019

Tujuan dari penelitian ini yaitu untuk mengetahui bagaimana peranan konselor dalam menanggulangi perilaku pergauan bebas yang terjadi di kalangan remaja sekolah. Subyek penelitian guru Bimbingan dan Konseling dan peserta didik SMA Muhammadiyah 2 Palangkaraya. Pengumpulan data dalam penelitinya dengan menggunakan wawancara, obsevasi analisis data menggunakan analisis deskriptif kualitatif. Dalam penelitian ini diharapkan tersusun sebuah laporan fisik penelitian dan ditambah dengan jurnal nasional tidak terakreditasi. Hasil penelitian menunjukan bahwasanya konselor memiliki peranan yang sangat vital. Faktor penyebab terjadinya pergaulan bebas terdiri dari 2 faktor yaitu factor internal dan eksternal. Faktor internal ialah faktor yang bersumber dari individu itu sendiri seperti kurangnya pemahaman agama dan remaja yang memiliki mental yang lemah. Adapun faktor eksternal ialah faktor yang bersumber dari luar yaitu lingkungan yang tidak kondusif seperti kurangnya perhatian orangtua, keadaan keluarga yang kurang harmonis (broken home), pengaruh lingkungan setempat, dan pengaruh media sosial. Upaya Konselor dalam mengatasi pergaulan bebas remaja di SMA Muhammadiyah 2 Palangkaraya yaitu dengan layana klasikal, konseling individu, dan bimbingan konseling kelompok.
\end{abstract}

*E-mail:

andiysetiawan@gmail.com

Orchid:
Kata Kunci: Peran Konselor, Pergaulan Bebas

\section{ABSTRACT}

The purpose of this study is to study how the role of the counselor in overcoming the behavior of freedom of association that occurs among school teens. The research subjects were Guidance and Counseling teachers and students of Muhammadiyah 2 High School in Palangkaraya. Data collection in the researcher using interviews, observation of data analysis using qualitative descriptive analysis. In this study it is expected to be composed of physical research reports and supplemented with non-accredited national journals. The results showed that counselors have a very vital role. The causes of promiscuity consist of 2 factors, namely internal and external factors. Internal factors are factors associated with individuals who have a lack of understanding of religion and adolescents who have a weak mentality. As an external factor, it is a factor related to the environment, namely an environment that is not conducive, such as consideration of the family, a less harmonious family environment, local environmental influences, and the influence of social media. The counselor's efforts in overcoming adolescent problems in Muhammadiyah 2 High School Palangkaraya are by classical services, individual counseling, and group counseling.

Keywords: Role of Counselors, Free Intercourse 


\section{PENDAHULUAN}

Salah satu tujuan utama dari pelaksanaan pendidikan adalah membina dan mendidik anak-anak bangsa memiliki keimanan dan ketaqwaan kepada Tuhan. Untuk mewujudkan hal tersebut perlu adanya peran pembimbing memberikan arahan pada siswa agar memeliliki pemahaman komunikasi yang baik dengan sesama, Sehingga mampu mewujudkan perilaku yang sesuai dengan keadaan masyarakat. Layanan bimbingan yang diberikan pembimbing harus dirancang sedemikian rupa harus diberikan secara kontinyu atau secara menerus untuk mengarahkan anak-anak menuju kedewasaan dengan demikian melalui pemberian bimbingan konseling akan menurunkan kenakalan remaja di sekolah. Kenakalan Remaja merupakan suatu perilaku patologis (penyakit masyarakat) karena disebabkan oleh beberapa faktor sehingga menjadi perbuatan yang menyimpang. Hal ini merupakan suatu perilaku yang meresahkan masyarakat, sekolah, keluarga. Sehingga perlu diperbaiki, disinilah peranan guru bimbingan dan konseling sangat diharapkan memperbaiki perilaku negatif tersebut. Mengingat luasnya tujuan bimbingan dan konseling bagi para siswa, tidak dapat dibantah bahwa guru memiliki peranan yang amat besar dibidang bimbingan dan konseling. Secara garis besarnya peran guru termasuk guru bimbingan dan konseling adalah mengkoordinir keberhasilan bimbingan dan konseling disamping kegiatan administrasi dan kurikulum (akademik). Artinya, maju mundurnya bimbingan dan konseling di sebuah sekolah menjadi tanggung jawab guru dan guru bimbingan dan konseling. Karena itu kepedulian utama kepala Sekolah sebagai manajemen puncak di Sekolah adalah menyediakan dana, sarana, dan tenaga konselor/BK profesional (lulusan bimbingan dan konseling SI, dan D3), Sofyan S. Willis (2010:29).

Guru bimbingan dan konseling adalah guru yang mempunyai tugas, tanggung jawab, wewenang dan hak secara penuh dalam kegiatan bimbingan dan konseling terhadap sejumlah peserta didik, tidak terkecuali peserta didik tuna netra yang secara fisik memiliki keterbatasan. Karena itu secara praktis peran guru bimbingan dan konseling di sekolah sangat dibutuhkan dalam rangka pengembangan karir atau kreativitas siswa, Ulifa Rahma (2010:65)

Menurut Baruth dan Robinson, peran adalah apa yang diharapkan dari posisi yang dijalani seorang konselor dan persepsi dari orang lain terhadap posisi konselor tersebut. Sedangkan peran konselor menurut Baruth dan Robinson adalah peran yang inheren ada dan disandang oleh seseorang yang berfungsi sebagai konselor (Namora Lumongga Lubis, 20II)

Ada banyak teori mengenai peran konselor, teori tersebut bermacam-macam sesuai dengan asumsi tingkah laku serta tujuan yang akan dicapai oleh seorang konselor. Dalam pandangan Rogers, koselor lebih banyak berperan sebagai partner klien dalam memecahkan masalahnya. Dalam hubungan konseling, konselor ini lebih banyak memberikan kesempatan pada klien untuk mengungkapkan segala permasalahan, perasaan, dan persepsinya, dan konselor merefleksikan segala yang diungkapkan oleh klien.

Selain itu peran konselor menurut Rogers adalah fasilitator dan reflektor. Disebut fasilitator karena konselor memfasilitasi atau mengakomodasi konseli mencapai pemahaman diri. Disebut reflektor karena konselor mengklarifikasi dan memantulkan kembali kepada klien perasaan dan sikap yang diekspresikannya terhadap konselor sebagai representasi orang lain. 
(Robert L. Gibson, Marianne H. Mitchell. 20II)

Agar peran ini dapat dipertahankan dan tujuan konseling dapat dicapai, maka konselor perlu menciptakan iklim atau kondisi yang mampu menumbuhkan hubungan konseling. Kondisi konseling ini menurut Rogers satu keharusan dan cukup memadai untuk pertumbuhan, sehingga dia menyebutnya sebagai necessary and sufficient conditions for therapiutic change (latipun. 20I5).

Penanggulangan siswa merupakan tanggung jawab bersama baik itu dari pihak orang tua, sekolah, maupun masyarakat. Kerjasama antara unsur-unsur terkait sangat diperlukan sehingga diperoleh hasil yang optimal dengan cara efektif dan efisien. Diantara usaha yang sangat penting dan dapat dilakukan oleh setiap orang tua, guru atau pemimpin masyarakat adalah dapat menciptakan ketentraman batin bagi remaja. Beberapa cara dalam mengatasi siswa bermasalah, meliputi : a. Pengenalan awal tentang kasus (dimulai sejak semula kasus itu dihadapkan) $b$. Pengembangan ide-ide tentang rincian masalah yang terkandung didalam kasus itu c. Penjelajahan yang lebih lanjut tentang segala seluk beluk kasus tersebut dan akhirnya $\mathrm{d}$. Mengusahakan upaya-upaya kasus untuk mengatasi atau memecahkan sumber pokok permasalahan itu. Prayitno dan Erman Amti (2013:77) Adanya keharusan guru bimbingan dan konseling mengenal karakteristik peserta didik tersebut, dalam hal ini guru bimbingan dan konseling sepatutnya mendalami psikologi perkembangan peserta didik, yakni sebuah disiplin ilmu yang secara khusus membahas tentang aspek-aspek atau karakteristik perkembangan peserta didik, Sofyan S. Willis (2010:29). Seorang guru pembimbing (konselor) konseling sekolah adalah orang yang memimpin suatu kelompok konseling sepenuhnya bertanggung jawab terhadap apa yang telah terjadi dalam kelompok itu. Dalam hal ini guru pembimbing (konselor) dalam institusi pendidikan tidak dapat lepas tangan dan menyerahkan tanggung jawab atas keberhasilan dan kegagalan kelompok sepenuhnya kepada para konseling sendiri. Ini berarti guru pembimbing baik dari segi teoritis maupun segi praktis harus bertindak sebagai ketua kelompok diskusi dan sebagai pengatur wawancara konseling bersama, W. S. Winkel (2005:495). Guru pembimbing harus memenuhi syarat yang menyangkut pendidikan akademik, kepribadian, keterampilan berkomunikasi dengan orang lain dan penggunaan teknikteknik konseling, Prayitno dan Erman Amti (20I3:II4).

Gagasan tersebut secara praktis jika dilakukan tidak semudah membalik telapak tangan dan bisa dipahami sebagai hal yang sulit untuk diwujudkan. Sebab, jumlah siswa di sekolah yang banyak tidak sebanding dengan keberadaan guru bimbingan dan konseling yang tersedia. Berbagai kesulitan dalam proses belajar mengajar ini sering dihadapi oleh para siswa di beberapa sekolah sehingga berdampak pada berbagai macam bentuk kenakalan remaja yang muncul salah satunya yaitu pergaulan bebas. Guru bimbingan dan konseling dituntut agar dapat memberikan pemahaman serta penguatan kepada para siswa sehingga dapat memperoleh solusi yang tepat dalam menyelesaikan permasalahnya. Guru Bimbingan dan Konseling menyelelesaikan atau menangani kenakalan para siswanya dengan cara pendekatan secara psikologis dengan melakukan konseling secara individu ataupun kelompok. Beranjak dari uraian di atas, maka penulis termotivasi untuk melakukan penelitian dengan judul: "Peran Konselor Dalam Penanggulangan Pergaulan Bebas Di Kalangan Remaja (studi kasus di SMA Muhammadiyah Palangkaraya)". Tujuan Penelitian yaitu untuk mengetahui peran guru bimbingan dan konseling dalam menangani kenakalan remaja khususnya pergaulan bebas. 


\section{METODE PENELITIAN}

Metode yang digunakan oleh penulis dalam penelitian ini adalah penelitian kualitatif. Pengumpulan data pada penelitian ini menggunakan wawancara, karena peneliti ingin menggali informasi kepada Guru Bimbingan dan Konseling bagaimana peran Guru Bimbingan dan Konseling dalam menangani kenakalan remaja. observasi karena peneliti ingin mengetahui informasi secara langsung dalam observasi di sekolah dan informasi kepada Guru Bimbingan dan Konseling dalam menangani kenakalan remaja. Analisis data pada penelitian ini dilakukan dengan analisis data kualitatif adalah bersifat induktif, yaitu suatu analisis berdasarkan data yang diperoleh, selanjutnya dikembangkan menjadi hipotesis. Berdasarkan hipotesis yang dirumuskan berdasarkan data tersebut, selanjutnya dicarikan data lagi secara berulang-ulang sehingga selanjutnya dapat disimpulkan apakah hipotesis tersebut diterima atau ditolak berdasarkan data yang terkumpul. Bila berdasarkan data yang dapat dikumpulkan secara berulang-ulang dengan teknik tiangulasi, ternyata hipotesis diterima, maka hipotesis tersebut berkembang menjadi teori

\section{HASIL DAN PEMBAHASAN}

Ada beberapa upaya yang dilakukan orangtua dalam mengatasi pergaulan bebas remaja di SMA Muhammadiyah 2 Palangkaraya yaitu memberikan bimbingan individu dan bimbingan kelompok.

\section{Bimbingan dan Konseling Individu}

Dalam kaitannya dengan bentuk upaya guru pembimbing dalam mengatasi pergaulan bebas di Sekolah dapat mengacu kepada layanan bimbingan konseling:
A. Bimbingan
I. Bimbingan Pribadi.
Dalam bidang bimbingan pribadi, pelayanan BK Sekolah Vokasional Pertanian

Chenor, membantu siswa menemukan dan mengembangkan pribadi yang beriman dan bertakwa kepada Allah SWT, mantap dan mandiri, serta sehat jasmani dan rohani.

\section{Bimbingan Sosial}

Dalam bidang bimbingan sosial, pelayanan BK Sekolah Vokasional Pertanian Chenor membantu pelajar untuk mengenal dan berhubungan dengan lingkungan sosialnya yang dilandasi budi pekerti yang luhur, tanggung jawab kemasyarakatan dan ke Negaraan akan lebih efektif bimbingan pribadipribadi yang akan diberikan pada jenjang menengah sebagai saluran melalui bimbingan kelompok dan sebagian lagi melalui bimbingan individual.

\section{Bimbingan Belajar}

Dalam bidang bimbingan belajar, pelayanan BK di Sekolah Vokasional Pertanian Chenor, membantu pelajar mengembangkan diri, sikap dan kebiasaan belajar yang baik, untuk menguasai pengetahuan dan keterampilan serta menyiapkan pelajar untuk melanjutkan pendidikan pada tingkat yang lebih tinggi. Selanjutnya Dewa Ketut Sukardi mengungkapkan, layanan dalam bimbingan belajar antara lain: mengenai pengembangan tentang pemahaman dalam kaitannya dengan cita-citanya, perkembangan kemampuan berkomunikasi, perkembangan sikap dan disiplin dalam belajar dan teknik penguasaan materi belajar.

4. Bimbingan Karir pelayanan BK di Sekolah Vokasional Pertanian Chenor membantu pelajar merencanakan dan mengembangkan masa depan karirnya.

\section{B. Bimbingan individu}

yaitu memberikan bantuan kepada individu agar dapat memecahkan permasalahan yang dialaminya. Adapun bimbingan individu yang dilakukan oleh orangtua dalam mengatasi pergaulan bebas remaja di SMA Muhammadiyah 2 Palangkaraya yaitu: 
Jurnal Bimbingan dan Konseling

\section{Bimbingan \& konseling Kelompok}

Bimbingan kelompok merupakan suatu upaya bimbingan individu melalui kelompok. Adapun bimbingan kelompok yang dilakukan oleh orangtua dalam mengatasi pergaulan bebas remaja di SMA Muhammadiyah 2 Palangkaraya yaitu:

\section{a. Memberikan Pendidikan Agama}

Pendidikan agama dan keyakinan yang sungguh-sungguh kepada Allah adalah kebutuhan jiwa yang pokok, yang dapat memberikan bantuan bagi si remaja untuk melepaskannya dari gejolak jiwa yang sedang menghebat dan menolongnya dalam menghadapi dorongan-dorongan negatif. Telah diungkapkan oleh seorang penyuluh agama Islam di Desa Paraili bahwa remaja yang diberikan pendidikan agama oleh orangtuanya akan meminimalisir terjadinya pergaulan bebas karena bisa mengendalikan diri dari perbuatan keji dan memiliki akhlak yang baik, insyaallah. Adapun salah satu cara yang perlu dilakukan untuk mengatasi pergaulan bebas remaja yaitu menyekolahkan di sekolah berbasis Islam. Ketika remaja ditempatkan di sekolah yang berbasis Islam, maka ia akan memperoleh pendidikan agama yang tidak diperoleh dari lingkungan keluarga dan memperoleh pendidikan agama yang lebih dalam ketimbang pendidikan yang diperoleh dari sekolah umum lainnya. Dengan demikian, remaja akan lebih sering menghabiskan waktu untuk beribadah seperti salat wajib, salat sunnah, puasa wajib, puasa sunnah, tadarrus, kegiatan yang bersifat positif lainnya sehingga remaja memiliki mental yang kuat yang tidak mudah goyah dengan hal-hal yang buruk. Contohnya seperti pengaruh media sosial.

Pendidikan agama dan spiritual merupakan pondasi utama bagi Pendidikan keluarga. Pendidikan agama ini meliputi pendidikan aqidah, mengenalkan hukum halal dan haram, memerintahkan anak beribadah (shalat dan puasa), mendidik anak untuk mencintai Rasulullah saw. , keluarganya, orang-orang yang shalih dan mengajar anak membaca Al-Qur'an. Memberikan pendidikan agama kepada remaja memang bisa mengatasi remaja dari pergaulan bebas.

Pentingnya bersabar dalam mengerjakan shalat, tidak boleh bosan, tidak boleh berhenti dan segera mengerjakan jika datang waktunya. Shalat tidak membawa keuntungan materi dan shalat tidak akan segera tampak hasilnya oleh mata. Shalat merupakan urusan ketentraman jiwa dan sekaligus merupakan doa. Dengan kesabaran melakukan shalat, jiwa akan terasa tentram dan pikiran menjadi tenang sehingga bisa berfikir jernih dan melahirkan semangat juang dan etos kerja yang tinggi. Allah Swt memberikan jaminan bahwa kalau seorang hambah benar benar menyerahkan diri kepada Allah swt, melaksanakan shalat dengan tekun dan keluarganya juga diajak tekun beribadah, niscaya Allah swt akan mengkaruniakan rezeki kepadanya.

\section{b. Mendorong Remaja untuk Mengisi Waktu Kosong dengan Kegiatan yang Bernilai Positif}

Salah satu cara agar remaja tidak membuang waktu mereka dengan malas malasan atau keluyuran tidak jelas yang nantinya bisa terjerumus ke dalam pergaulan bebas, lebih baik waktunya digunakan dengan kegiatan yang bernilai positif. Remaja terdorong untuk mengisi waktu kosongnya dengan melakukan kegiatan yang bernilai positif itu bisa mengatasi terjadinya pergaulan bebas pada saat ini. Ketika orangtua berhasil mendorong remaja tersebut seperti menunaikan shalat, belajar keagamaan, mengikuti pengajian rutin, berkarya sesuai hobbynya yang bisa membanggakan orangtua bahkan negara atau membuat kegiatan sosial lainnya yang berguna seperti mengumpulkan bantuan untuk korban bencana alam atau mengumpulkan teman temannya untuk diajak kerja bakti, maka remaja akan bisa merasakan manfaat yang besar ketika mereka melakukan 
Jurnal Bimbingan dan Konseling

hal itu dibandingkan menghabiskan waktu kosong dengan hal-hal yang tidak penting hingga terjerumus dalam pergaulan bebas.

Orangtua yang memiliki niat baik dapat mengatasi pergaulan bebas pada anaknya, namun jika dilakukan dengan paksaan atau bahkan melakukan kekerasan itu justru membuat perilaku remaja semakin buruk. Peran orangtua sangat diperlukan untuk mendorong remaja mengisi waktu kosongnya dengan melakukan kegiatan yang bernilai positif. Karena orangtua merupakan pendidik utama. Untuk mendorong remaja mengisi waktu kosongnya dengan melakukan kegiatan yang bernilai positif, orangtua harus pintar menarik perhatian remaja tersebut tanpa harus memaksa atau bahkan melakukan kekerasan.

\section{Layanan Klasikal}

a. Layanan orientasi yaitu layanan bimbingan dan konseling yang memungkinkan pelajar (klien) memahami lingkungan (seperti sekolah) yang baru dimasuki pelajar, untuk mempermudahkan dan memperlantarkan berperannya pelajar dilingkungannya yang baru itu.

b. Layanan informasi yaitu layanan bimbingan dan konseling yang memungkinkan pelajar menerima dan memahami berbagai informasi pendidikan dan informasi jabatan.

c. Layanan penempatan dan penyaluran yaitu salah satu layanan yang memungkinkan pelajar memperoleh penempatan dan penyaluran yang tepat misalnya penempatan dan penyaluran dalam kelas, kelompok belajar, jurusan/program studi dll.

d. Layanan pembelajaran/konten yaitu layanan bimbingan dan konseling yang memungkinkan pelajar mengembangkan diri dengansikap dan kebiasaan belajar yang baik. e. Layanan bimbingan kelompok yaitu layanan yang memungkinkan sejumlah pelajar secara bersama-sama melalui dinamika kelompok memperoleh berbagai bahan melalui pembahasan dalam bentuk kelompok.

f. Layanan konseling kelompok yaitu layanan yang memungkinkan sejumlah pelajar memperoleh kesempatan untuk pembahasan dan pengentasan permasalahan yang dialaminya melalui dinamika kelompok; masalah yang dibahas itu adalah masalah-masalah pribadi yang dialami oleh masingmasing.

Layanan konseling perorangan yaitu layanan bimbingan dan konseling yang memungkinkan pelajar mendapat layanan langsung tatap muka (secara perorangan) dengan guru pembimbing dalam rangka pembahasan dan pengetasan masalah pribadi yang dialami pelajar.

\section{KESIMPULAN}

Faktor penyebab terjadinya pergaulan bebas terdiri dari 2 faktor yaitu factor internal dan eksternal. Faktor internal ialah faktor yang bersumber dari individu itu sendiri seperti kurangnya pemahaman agama dan remaja yang memiliki mental yang lemah. Adapun faktor eksternal ialah faktor yang bersumber dari luar yaitu lingkungan yang tidak kondusif seperti kurangnya perhatian orangtua, keadaan keluarga yang kurang harmonis (broken home), pengaruh lingkungan setempat, dan pengaruh media sosial.

Upaya orangtua dalam mengatasi pergaulan bebas remaja di SMA Muhammadiyah 2 Palangkaraya yaitu bimbingan dan konseling individu dan bimbingan konseling kelompok. Bimbingan individu yaitu memberikan bantuan kepada individu agar dapat memecahkan permasalahan yang dialaminya seperti memberikan perhatian dan kasih sayang, 
memberikan contoh yang baik dan menanamkan kedisiplinan pada remaja. Adapun bimbingan kelompok merupakan suatu upaya bimbingan individu melalui kelompok seperti memberikan pendidikan agama dan mendorong remaja untuk mengisi waktu kosong dengan kegiatan yang bernilai positif. .

\section{DAFTAR PUSTAKA}

Aryani, F. 2016. Stres Belajar Suatu Pendekatan Dan Intervensi Konseling. Sulawesi Tengah: PT Edukasi Mitra Grafika

Astuti, B. 20I2. Modul Konseling Kelompok Abu Ahmadi. 2005. Bimbingan dan Konseling di Sekolah, Yogyakarta: Pustaka Pelajar.

Alwisol. 2007. Psikologi Kepribadian, Malang: UMM Press.

Claudia Nef Saluz. 2009. Dynamics Of Islamic Student Movements: Iklim Intelektual Islam Di Kalangan Aktivis Kampus, Yogyakarta: RESIST BOOK.

Dede Rahmat Hidayat dkk. 2013. Bimbingan dan Konseling Kesehatan Mental di Sekolah, Bandung: Remaja Rosdakarya.

Dewa Ketut Sukardi. 2008. Proses Bimbingan Dan Konseling Di Sekolah. Jakarta: Rineka Cipta

Djunaidi Ghony, dkk. 20I2. Metode Penelitian Kualitatif. Yogyakarta: Ar-Ruzz Media.

Kartini kartono. 2003. Pathologi Sosial II, Kenakalan Remaja. Jakarta: Raja Granfindo Persada.

Latipun. 20I5. Psikologi Konseling. Malang: UMM Press

Namora Lumongga Lubis. 20II. Memahami Dasar-dasar Konseling. Jakarta: Kencana

Permendikbud No. III tahun 2014 tentang Bimbingan dan Konseling pada Pendidikan Dasar dan Pendidikan Menengah.
Prayitno dan Erman Amti. 2013. Dasar-Dasar Bimbingan dan Konseling, Jakarta: Rineka Cipta.

Robert L. Gibson, Marianne H. Mitchell. 20II. Bimbingan Dan Konseling, (Yogyakarta: Pustaka Pelajar

Ruslam Ahmadi. 2014. Metodologi Penelitian Kualitatif. Yogyakarta: AR-RUZZ MEDIA.

Sofyan S. \& Willis. 2007. Problema Remaja dan Pemecahan nya. Bandung: Angkasa. 2010. Konseling Individual: Teori dan Praktik, Bandung: Alfabeta.

Sudarsono. 2004. Kenakalan Remaja. Jakarta: Rineka Cipta.

Sugiyono. 20II. Metode Penelitian Kuantitatif \& Kualitatif, Bandung: CV. Alfabeta.

Suharsimi Arikunto. 2006. Prosedur Penelitian Suatu Pendekatan Praktik. Jakarta: Rineka Cipta.

Syamsu Yusuf. 2005. Psikologi Perkembangan Anak dan Remaja, Bandung: PT. Remaja Rosdakarya.

Ulifa Rahma. 2010. Bimbingan Karir Siswa, Malang: UIN- Maliki Press.

W. S Winkel. 199I. Bimbingan Dan Konseling Di Institusi Pendidikan. Jakarta: PT. Grasindo

Winkel. W. S. 2005. Bimbingan Dan Konseling di Institusi Pendidikan, Jakarta: PT. Grasindo 